\title{
特集 観光と不動産【論説】
}

\section{「民泊」とは何か？：経済学の視点}

What is "Private Lodging"? : The Perspective of Economics

Masayuki NAKAGAWA : Nihon University

中川 雅之*

\section{1. はじめに}

別荘を含む住宅の一部を他人に有償で貸し出す, いわゆる「民泊」に関連するルールを定めた住宅 宿泊事業法が，2019年 3 月に施行される。このよ うな制度が制定された背景としては，国において， 2020年までに訪日外国人観光客数を 4000 万人に増 やす，2030年までに6000万人に増やすという目標 が揭げられている一方で, 宿泊施設の不足が現時 点においても明らかになっていることが挙げられ る。このような環境下,「民泊」はそれを解決す る手段の一つとして大いに期待されていた。

元々国家戦略特区などにおいては，「民泊」が 一定の条件下で認められていたが, それを全国に 拡大する措置として住宅宿泊事業法は制定された。 しかし, 当該法においては, 年間180日を上限に 住宅地での「民泊」を認める一方で, 地方自治体 ごとに営業日数や時間, 対象地域などに規制をか けることができるようになっている。このため各 自治体では, 現時点で筆者が把握している限り, かなり厳しい上乗せ規制が導入されつつあるよう に考える。例えば, 東京都中央区においては区内 全域で月曜の正午から土曜の正午までの営業が制 限される。また, 軽井沢町では民泊施設を町内全 域で認めない方針が明らかにされている。京都市 においては, 住居専用地域について $1 \sim 2$ 月に限
定し, つまり約60日間のみ営業を認める方針とさ れている。

このような動きをどのように受け止めるべきな のだろうか。本稿では経済学の考え方に沿って, 「民泊」という経済活動をどのように受け止め, 特に中央政府，地方政府などの公共部門は，どの ようにそれに対応することが期待されるのかにつ いて議論を行いたい。

\section{2.「民泊」とは何か?}

「民泊」に限らず，宿泊サービスを提供するビ ジネスは, 耐用年数の長い固定設備で宿泊サービ スの提供を行う必要があるため, 変動する需要へ の対応が難しいという特徴があると考えられてい る。特に東京オリンピックのような, 短期間に限 定された大きな需要が発生する場合には, その対 応は大きな困難を伴う。このような特徵は, オリ ンピックのような非常に大きなイベントに限らず, 各地域で行われている伝統的な, あるいは地域お こしのために生み出されたイベントなどについて も共通する課題であろう。もし，供給レベルをあ る期間中固定的に考えざるを得ないのであれば, 図 1 にあるように，固定設備が供給しうる宿泊 サービスのレベルをどこに設定するかによって， 「需要減少期の遊休化を許容するのか」, 又は「需 要増大期における混雑を許容するのか」を必然的 


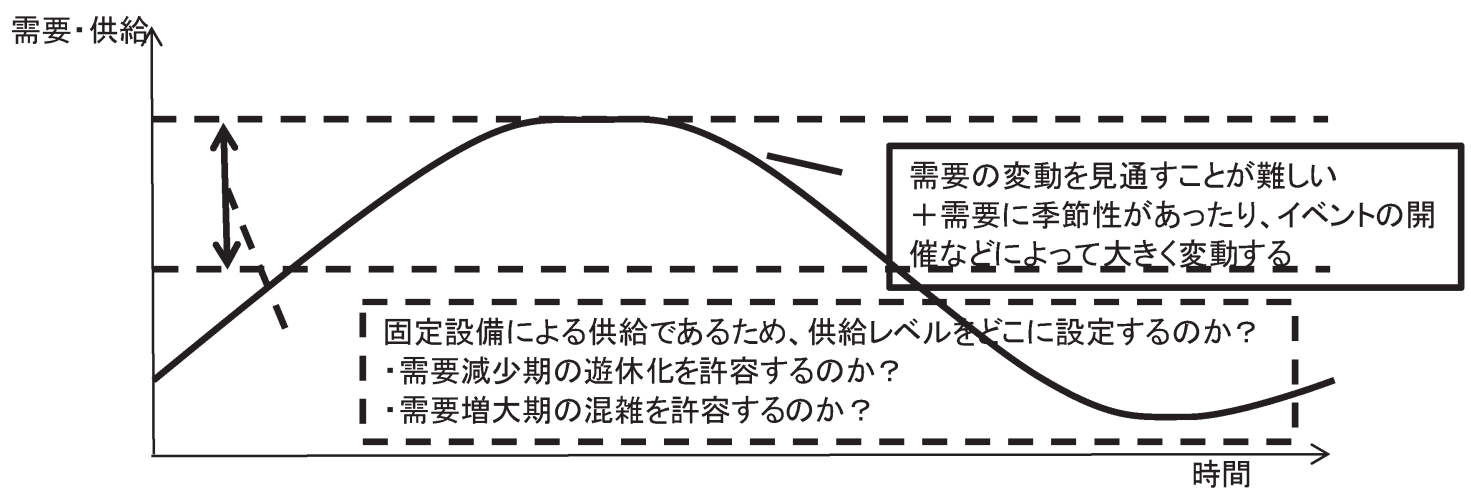

図 1 宿泊サービス事業の特徵

に選択しなければならない。

しかし，供給レベルを需要に応じて柔軟に調整 することができるならば, 需要と供給のミスマッ チは緩和され，宿泊サービスの売り手にとっても 買い手にとっても好ましい状況が生じる。この供 給レベルの調整は，これまでには，大きな設備投 資を伴う固定設備のレベルの変更, 又は旅館業者 の参入と退出によって行われてきたと考えられる。

「民泊」とは，図 2 にあるように，大規模な設 備投資, 設備の改廃, 旅館業者の参入, 退出によ らずに家計に分散して存在する，「宿泊サービス を提供しうる」不動産ストックを利用してこの需 給調整をする仕組みとして位置づけることができ よう。

それではなぜ図 2 にあような分散型の宿泊 サービスが提供されなかったのか。一つは住宅 サービスが住宅ストックから発生するものと考え た場合，日本においては住宅ストックが不足ある いは不十分な状況が長く続き, 他人に宿泊サービ スを提供する余裕がなかったことが挙げられる。 もう一つは, 分散型の不動産ストックを宿泊サー ビス提供に結びつける技術がなかったことが挙げ られる。

\section{3. 分散型不動産ストックの出現}

まず前者について説明しよう。図 3 にあるよう に1948年における日本の空家数は約 6 万戸（空家
率 $0.4 \%$ ）にすぎない。終戦後しばらくは，住宅 ストック数を世帯数が上回る住宅不足の時代がし ばらく続いた。その後, 住宅整備が順調に進んだ ことを背景に，空家率も1980年代には10\%程度ま で上昇した。住宅のフレキシブルな流通に必要で あるとされる自然空家率がどの程度なのかは, 確 定的には言えないが，これらの時期において空家 の存在が大きな問題となることはなかった。一方， 日本が人口減少時代に入った 2000 年代には空家数, 空家率とも上昇し，2013年段階で空家数は853万 戸，空家率14\%に達している。このように，日本 の住宅は量的には過剩なストックが存在する状況 に大きく変わっている。

このような空家としての「宿泊サービスが提供 可能な」住宅ストックは, 都市ごとにまとまって いるのではなく, 異なる所有者によって, 都市内 に点在して存在している。

しかし，空家については既に老朽化しているた めに,「住宅サービス」を提供することが叶わな いものとなっているもの含まれているだろう。 「住宅サービス」を提供することが困難な住宅ス トックを「宿泊サービス」の用に供するには, 改 修や建替えなどの大規模な設備投資が必要になる かもしれない。また，住人がいないために魅力の ある宿泊サービスを提供することが困難である可 能性もあろう。

このため現に人が住んでいる住宅について，世 


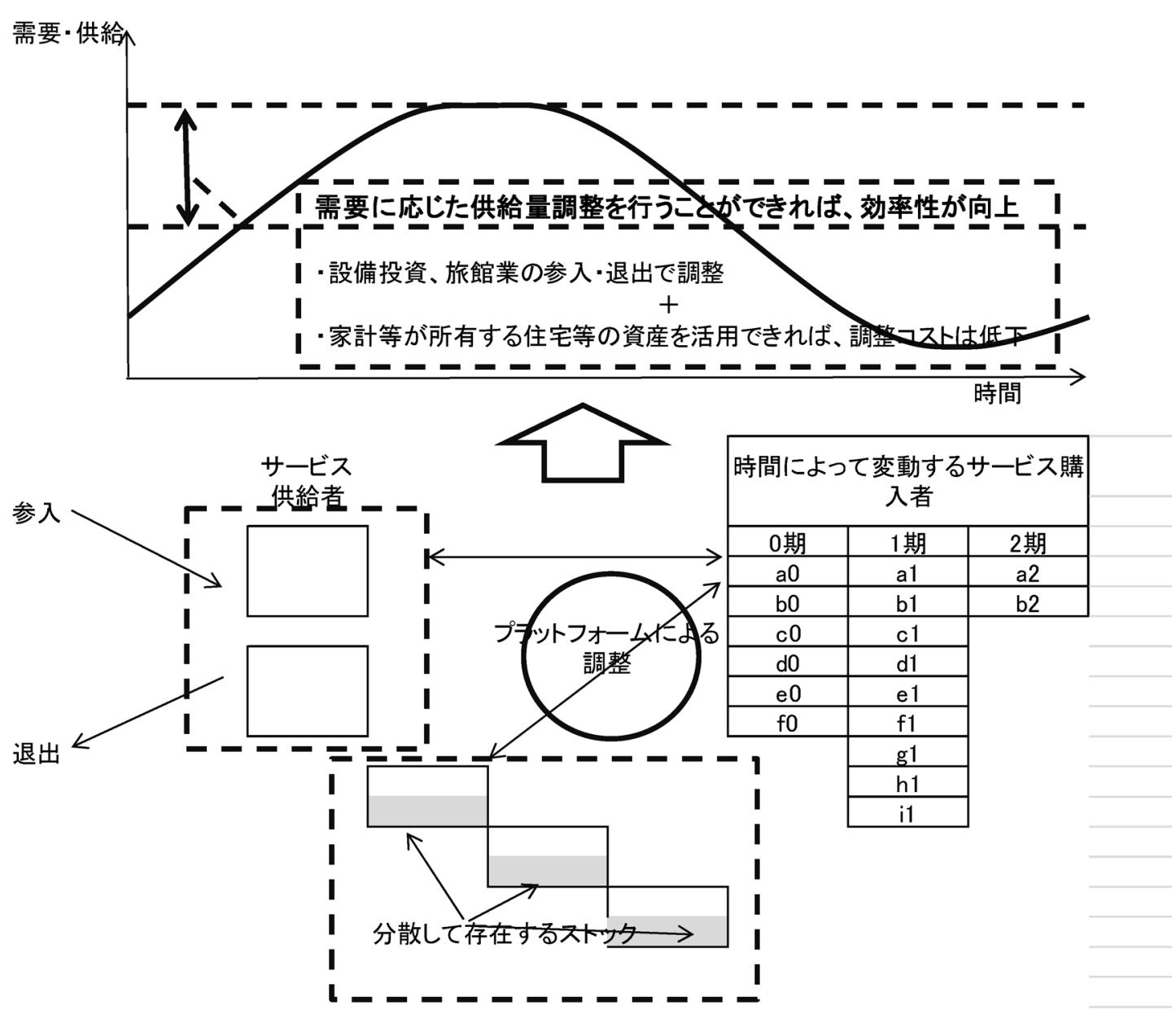

図 2 「泊」の位置づけ

帯人数と住宅の部屋数の関係の2003～2013年の変 化を, 住宅土地統計調査によってみてみよう。図 4 の三次元の棒グラフには2003〜2013年の世帯人 数 (平面の縦軸), 住宅の室数 (平面の横軸) ご との増減数が描かれている。

この10年で単身世帯が大きく増えたために, 手 前の一人世帯が 1 室及び 3 室から 7 室程度の住宅 大きく増加していることがわかる。これをよりわ かりやすくするために, 図 5 では（世帯人数一住 宅の室数）を横軸にして，2003～2013年における 増減を表している。

ここからは, 世帯数と住宅の室数が同じ組み合 わせだけでなく，世帯数よりも2 室〜 5 室多い
「世帯と住宅の組み合わせ」がこの10年間で大き く増加していることがわかる。

図 6 においては，2013年時点での（世帯人員数 一住宅の室数) ごとの住宅ストック数が描かれて いる。図 6 からは2013年のストックベースでは世 帯人員と同じあるいは 2 室程度大きな住宅に住ん でいる，世带×住宅の組み合わせが主たるものと なっているが, 図 5 から読み取れるのは, それよ りも右側の部分つまり個々の住宅での使用頻度が 低いであろうスペースを生じさせてしまう組み合 わせが，大きく増えていることがわかる。少子高 齢化や家族関係の変化を背景に, このような動き は今後も継続することが予想される。 


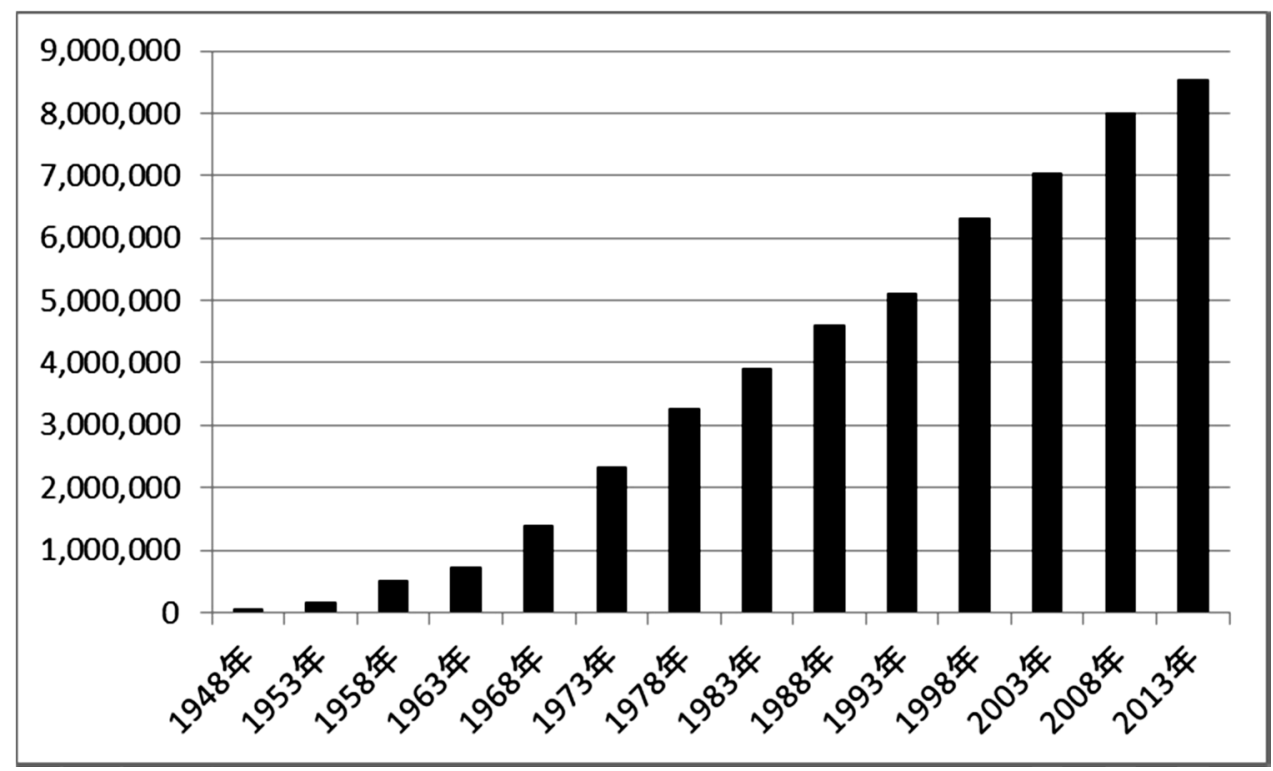

図 3 空家数の推移

注)「住宅土地統計調査」(H25年) (総務省統計局) より筆者作成

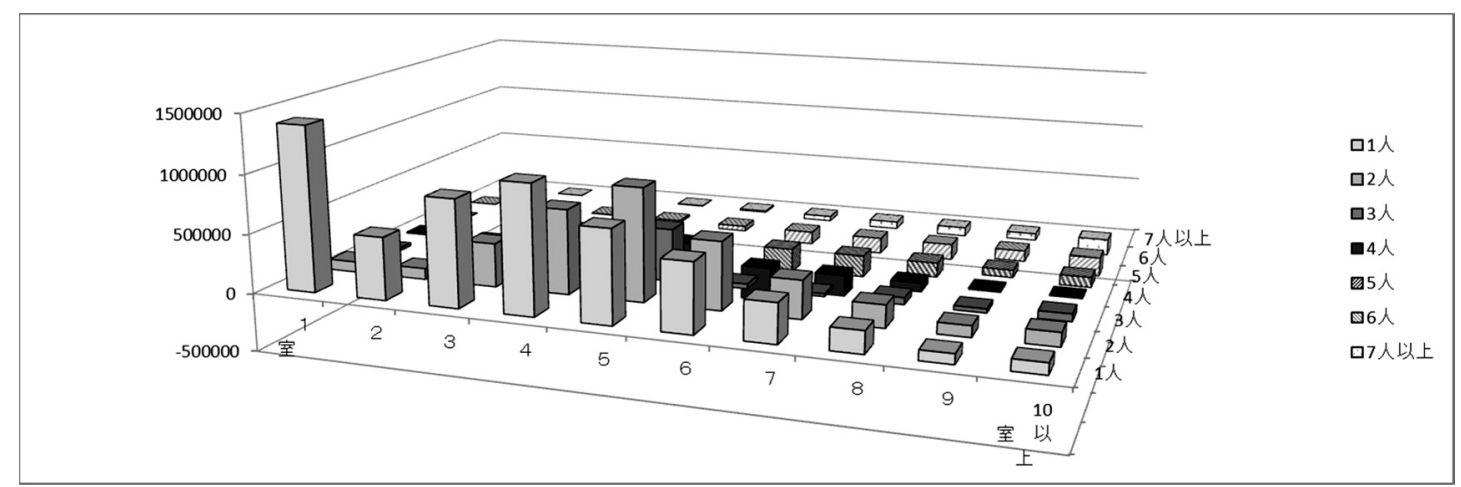

図 4 2003 2013年の世帯人員 $\times$ 住宅の室数の組み合わせ変化

注)「住宅土地統計調査」(H 5 年及びH 25 年)（総務省統計局）より筆者作成

つまり日本においては，空家という住戸単位のみ ならず, 住戸の空室という室単位で, 宿泊サービ スを提供しうる分散型の不動産ストックが大量に 出現する時代に突入していることが窅える。

\section{4. テクノロジーの発展}

次に,テクノロジーとの関係について議論をし よう。一部繰り返しになるが, 分散型の不動産ス トックを利用した宿泊サービスが提供されなかっ
た理由を整理しよう。

(1) 分散型の不動産ストックは, 個々人が所有し ているものであり，あるいは時間的に常時発 生しているものではないため, それと需要を マッチングすることが難しかった。

(2) 需要側は, (1)のように分散して存在している 大量の宿泊サービスの質を知ることができな い情報の非対称性があった。

(3) 宿泊サービスを提供するためには, 決済, 需 


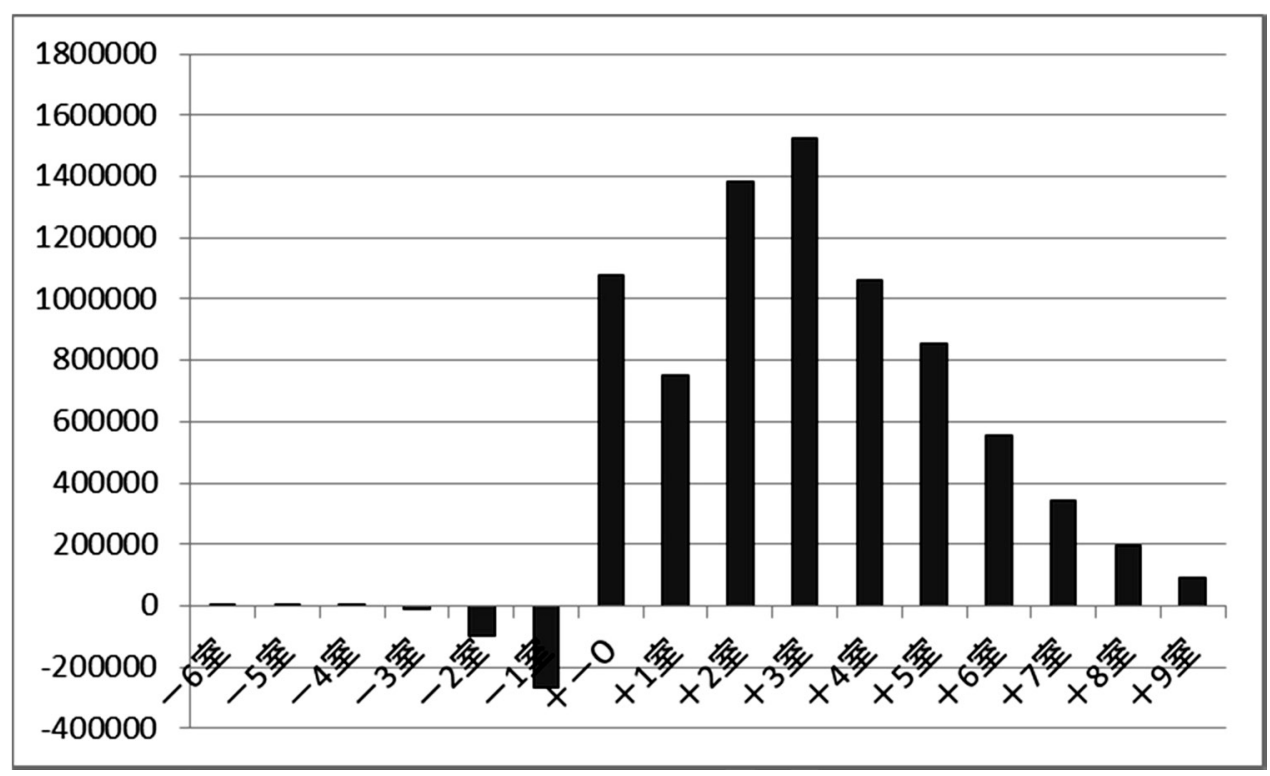

図 5 (世帯人数一住宅の室数) の2003～2013年の変化

注)「住宅土地統計調査」(H 5 年及びH25年) (総務省統計局) より筆者作成

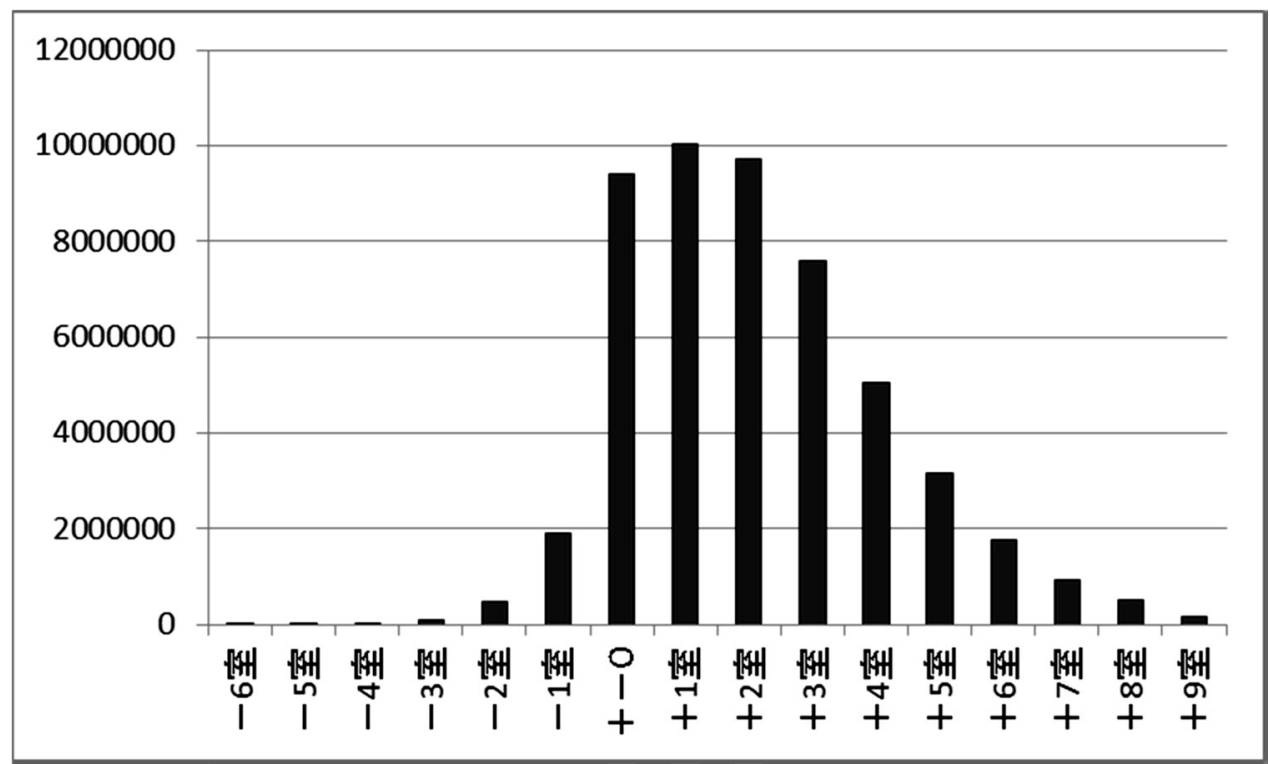

図 6 （世帯人数一住宅の室数）の2003～2013年の変化

注)「住宅土地統計調査」(H25年) (総務省統計局) より筆者作成

要者とのマッチングなど一定の固定費が必要 であり，個々人が片手間にそれを行うことは 困難だった。

などの理由が挙げられる。しかし, 図 2 におい
て図示したプラットフォーム，具体的にはAir B \&Bなどのサービスが(1)〜(3)の問題の一定の解決 を図ることに成功している。具体的には,

(1) ITテクノロジーが, 分散型の不動産ストッ 
クと分散している需要者とのマッチングを行 うプラットフォームの出現を可能とした

(2) テクノロジーが事前の詳細な情報提供, さら に，これまでの利用者の評価を提供すること で，情報の非対称性を緩和することに成功し た

(3) テクノロジーが安価に, 個々人でもマッチン グ，決済などのサービスを行えるインフラを 提供した

ことにより，図2のような分散型の不動産による 宿泊サービスの需給調整が可能になったとされて いる。

実際にAir B\&Bに関する実証研究を行った Zervus and Proserpio(2017) によれば, Air B\&B の参入は既存のホテルの部屋の稼働率をやや低下 させ，価格を引き下げる効果を持ったとされてい る。このことは，既存のホテルの収益を一部引き 下げたことを意味するものの，対象地域に泊まれ なかった需要者に対するサービス提供が可能に なったり，またより安価にそれが可能になったこ とを意味する。

しかし, 全てのホテルについて同じ効果が生じ たわけではなく, High Endのホテルはほとんど 影響がなく，Air B\&Bを通じた宿泊サービスは Low Endのホテルの不完全な代替サービスに なっているという結論をこの論文では出している。 また，価格を引き下げる効果は，特にイベント開 催時などの需要ピーク時に大きく, Air B\&Bサー ビスは, 既存ホテル産業のpeak prcing powerを 大きく低下させるという効果を通じて, 人々の厚 生水準の上昇に貢献しているとされている。

これらのことを考え合わせれば，「民泊」とは， テクノロジーの進歩が可能にした宿泊サービスを 提供する産業への新規参入だ, 基本的には受け 止めることができる。その場合, 何等かの特別な 理由がない限り，参入規制を行うことは正当化さ れないということが，標準的な立場ではないだろ うか。その点について簡単に議論を行おう。

\section{5. どのような介入が正当化されるのか？}

新規参入に関して何等かの介入が必要な理由と して挙げられるのは, 提供される財やサービスに 関して情報の非対称性が存在する場合, その品質 を保証とするための最低限の基準の要求とそれを 担保するための許可や認定などの措置である。そ れが，公衆衛生の観点などから大きな外部性を引 き起こす場合には, 厳格な措置が要求される。こ れらの観点から, 旅館業法簡易宿泊営業を営む際 には公共部門の許可が必要になっている。しかし， これらの安全衛生上の観点からの規制は，レント， 超過利潤を確保するための参入規制となっている 場合があるため, そもそもこのような措置が宿泊 サービスの提供にあたって必要十分なものとなっ ているという点は, 再度議論が必要ではないだろ うか。さらに，情報の非対称性は，プラット フォーム上公開されている過去のサービス受給者 による評価により，相当程度緩和されるものと なっていることも考慮に入れる必要があるだろう。

次に, 周囲への外部不経済が生じる場合が挙げ られる。これは, 地方自治体にとって最も大きな 問題として受け止められている。例えば，「民泊」 のゲストが深夜まで騒いだり, マンションのルー ルを守らずにゴミを捨てたりすることで，近隣住 民とのトラブルに発展するということがあるとさ れている。「隣にどんな居住者がいるのか」とい うのは, neighborhood riskとして元々どのよう な場合でも生じるものであるが，一定以上の期間 は居住するであろう近隣住民が前提となる場合に は，そのリスクにさらされる回数は限定的なもの であろうし，長期間にわたって近隣関係が続くこ とが前提となれば，お互いにあまり身勝手な行動 はとらないというのが普通だろう。しかし，観光 客のように非常な短期的に近隣者が入れ替わり立 ち替わり出現するという状況では, この neighborhood riskが非常に大きなものになるか もしれない。住宅宿泊事業法で, 旅館業法では求 められていない, 宿泊者への説明義務や苦情解決 
の義務, 住宅宿泊事業の届け出時にマンション管 理規約, 賃貸住宅の賃貸契約書の確認などを求め ているのは, これらを配慮したものであろう。ま た現在, 非常に多くの自治体で, 旅館の立地が認 められていない住居専用地域では非常に限定的な 「民泊」の運用を行う条例を上乗せで定めようと しているのは, 上記のような背景があるものと考 えられる。

\section{6. おわりに}

このように, 住宅宿泊事業法に地方自治体が条 例で更なる限定的な運用を行おうとしていること 自体について, 理由がないという立場には筆者は 立たない。しかし, 我々は, 今一度立ち止まって 考え直す必要がある部分が数多くあるのではない か。

前述の通り, 日本において, 居住用として整備 された不動産ストックが, 分散して余剩化してい くことは, 今後の人口減少, 少子高齢化を考えれ ば回避できないものであろう。その一方で，訪日 外国人客数は大きく伸長し, 日本が生み出す付加 価值の一つの源泉として成長しつつある。また, 現在審議されている出入国管理法改正のように, より多くの外国人労働者を将来的に受け入れざる
を得ないという議論も始まっている。このような 中で, 我々はどのような社会が待ち構えているか について，想像力を働かした上でneighborhood riskについて基準となる期待, 参照点をもう一度 考え直すことが必要ではないだろうか。その場合, 自治体ごとに，用途に応じて一律に「民泊」が規 制されるということよりも，より小地域の外部性 が及ぶ範囲での住民の合意を根拠に，より柔軟な 対応が可能となる制度も今後検討されるべきだろ う。

最後に, 経済学的にはこれまでに議論したよう な, 安全や衛生等の観点からの介入はきちんとし た議論が必要だと考えるが, 住宅宿泊事業法に よって定められている180日以内の営業日の規制 のような, 既得産業を守る観点からとしか解釈し えない規制は，できるだけ速やかに緩和，撤廃が 行われるべきと考える。

\section{参考文献}

Zervus, G. and D. Proserpio(2017), “The rise of sharing economy: Estimating the impact of Air B\&B on the hotel industry”, Journal of Marketing Research, vol54(5),pp687-705 